\title{
Acute Toxicity and Hazardous Concentrations of Zinc to Native Freshwater Organisms Under Different pH Values in China
}

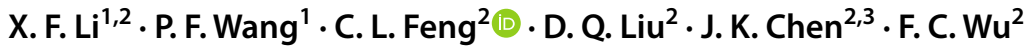

Received: 2 July 2018 / Accepted: 6 September 2018 / Published online: 24 September 2018

(c) The Author(s) 2018

\begin{abstract}
Zinc bioavailability to aquatic organisms varies greatly under different $\mathrm{pH}$ values. In the present study, five native species in China and four common international test species were selected to investigate the influence of changing $\mathrm{pH}$ on acute zinc toxicity. The results showed that the higher trophic levels exhibited increasing sensitivity to zinc as $\mathrm{pH}$ decreased. However, when the $\mathrm{pH}$ value was between 8 and 11, the acute toxicity of zinc was relatively constant. In addition, by using a speciessensitivity distribution (SSD) method, the short-term hazardous concentrations of zinc at different $\mathrm{pH}$ values (based on the 5th percentiles of the $\mathrm{pH}$-specific SSDs) were determined to be $17.26 \mu \mathrm{g} / \mathrm{L}(\mathrm{pH} 4), 48.31 \mu \mathrm{g} / \mathrm{L}(\mathrm{pH}$ 5), $80.34 \mu \mathrm{g} / \mathrm{L}(\mathrm{pH} 6)$ and $230.6 \mu \mathrm{g} / \mathrm{L}(\mathrm{pH} 7)$, respectively. The present study provides useful information for deriving water quality criteria and assessing the risks of metals in the near future.
\end{abstract}

Keywords Zinc $\cdot$ Native aquatic species $\cdot$ Hazardous concentration $\cdot \mathrm{pH} \cdot$ Water quality criteria $\cdot$ Metal bioavailability

Zinc is widely distributed throughout the natural environment and is also an essential trace element for aquatic organisms and humans (Wang et al. 2000). When the dose of zinc exceeds a certain amount, it may cause adverse effects to the organisms (Lindholmer 1974; Smirnova and MelNichenko 1997; Wadige et al. 2017; Wu et al. 2011). According to the water quality criteria for zinc issued by the US EPA (2009), the criteria of zinc to protect freshwater aquatic organisms are $120 \mu \mathrm{g} / \mathrm{L}$ (short -term hazardous concentration) and $120 \mu \mathrm{g} / \mathrm{L}$ (long-term hazardous concentration), while the criteria for human health are $7400 \mu \mathrm{g} / \mathrm{L}$ (ingested potable water + edible aquatic organisms grown in the water) and $26,000 \mu \mathrm{g} / \mathrm{L}$ (edible aquatic organisms only). It is evident

Electronic supplementary material The online version of this article (https://doi.org/10.1007/s00128-018-2441-2) contains supplementary material, which is available to authorized users.

C. L. Feng

fengcl@craes.org.cn

1 College of Environment, Hohai University, Nanjing, China

2 State Key Laboratory of Environmental Criteria and Risk Assessment, Chinese Research Academy of Environmental Sciences, Beijing, China

3 Faculty of Environmental Science and Engineering, Kunming University of Science and Technology, Kunming, China that aquatic organisms are much more sensitive to zinc concentrations in water than humans. According to the statistics of the National Bureau of Statistics of China in 2016, China is the second largest country in the world with zinc reserves, extraction, import and consumption (Guo and Feng 2013). Fu et al. (2016) reported that concentrations of zinc in Tai Lake were detected to be $0.018-1.246 \mathrm{mg} / \mathrm{L}$, and approximately $50.7 \%$ of the aquatic organisms were predicted to be affected by zinc. In Songhua River in China, concentrations of zinc were from 0.92 to $70.81 \mathrm{mg} / \mathrm{L}$ (Liu et al. 2017). Therefore, the exposure risk to aquatic organisms due to zinc greatly exceeds that of other countries. Thus, the potential toxicity of zinc to aquatic organisms in China should receive more attention (Wu et al. 2011, 2012).

Presently, much research has been conducted on aquatic toxicity effects of zinc. For example, the main research direction of European and American countries focused on the toxic effects on Salmonid fishes, shrimp, flea, hydroids and phytoplankton genera (Alsop and Wood 1999; Diamantino et al. 2003; Heijerick et al. 2003; Karntanut and Pascoe 2002; Mottin et al. 2010; Muyssen and Janssen 2007; Nor 1990; Ryan et al. 2009). Due to the differences in the aquatic species, quantity, nutritional structure and other characteristics between China and European and American areas, Chinese investigators further studied the toxic effects of zinc on common Cyprinid fishes and other species exhibiting 
regional characteristics of China and Asia (Feng et al. 2013; Wu et al. 2011, 2012). However, most research studies only considered the zinc toxicity effect on single species such as fish, benthic animals or phytoplankton. Further, the influences of variations in natural water environmental factors on zinc toxicity were not considered.

The toxicity of metals is significantly influenced by physical and chemical parameters of water quality such as hardness, pH, and temperature (Alsop and Wood 1999; Clifford and McGeer 2009; Ryan et al. 2009; Zhao et al. 2010). The $\mathrm{pH}$ values of the rivers and lakes in different regions of China are very different, and seasonal changes are also obvious (Fu et al. 2016). There are also significant differences in the toxicity of metals in various water bodies. Some of the lakes or rivers may be acidic $(\mathrm{pH}<6)$ or alkaline $(\mathrm{pH}>9)$ for a short time if they were polluted by industrial wastewater or influenced by algae blooms (You et al. 2007; Yu et al. 2013). However, most of the current studies were carried out when the $\mathrm{pH}$ was in the range of $6-8$, and they rarely addressed changes in the toxicity effect of zinc on aquatic species in acidic and basic water bodies (US EPA 2007). At the same time, the criteria and standard values established by each country, according to toxicological data, were created under conditions when the $\mathrm{pH}$ values of different water bodies were in the range of $6-8$, which is not in accord with the actual situations of water bodies.

To address influence of the aforementioned physicochemical water quality parameters on metal toxicity, a biotic ligand model (BLM) was developed to predict the toxicity of metals in the environment. The model comprehensively considers various water factors and action for the free metal ion bio-ligands (And and Wood 2004; Clifford and McGeer 2009; Heijerick et al. 2003; Ryan et al. 2009; Schamphelaere et al. 2005). The US and the EU BLM models for zinc are able to make predictions for safe concentrations based on test data for salmonid and warm-water fishes, invertebrates, and aquatic plants. However, almost all of the extensive data are restricted to North American and European temperate aquatic species tests, so there are still some questions with regard to the applicability of these BLMs to predict the sensitivity of the native species in China (Feng et al. 2013; Wang et al. 2006; Zhang et al. 2017). At the same time, judging from the accuracy of the predictions of the BLM, even if the responses of North American species are predicted, the predicted result is not very satisfactory (Chen et al. 2010).

Therefore, in the present study, five native species in China and four common international test species were chosen as test organisms to elucidate the effects of $\mathrm{pH}$ on zinc toxicity in a wide range of $\mathrm{pH}$ values (3-11). The aims of the study were to (1) explore the changes in the zinc toxicity effect on the aquatic organisms in environments with different $\mathrm{pH}$ values and (2) compare the short-term hazardous concentration differences under different $\mathrm{pH}$ values with the current acute water quality criteria for zinc. Further, the results might provide an important part of the scientific basis for the establishment and management of water quality criteria or standards for zinc and other metals under complicated water quality conditions.

\section{Materials and Methods}

The reagent $\mathrm{ZnSO}_{4} \cdot 7 \mathrm{H}_{2} \mathrm{O}$ with $99 \%$ purity was purchased from the Sigma-Aldrich Chemical Company in the USA. The laboratory uses various sources of natural waters to mix with deionized water for at least $24 \mathrm{~h}$ to prepare standard dilution water according to OECD standards (1992, 2004, 2011). The physical and chemical parameters of the standard diluted water are $\mathrm{pH}=7.8 \pm 0.2$; dissolved oxygen concentration above $80 \%$; hardness of $250 \pm 25 \mathrm{mg} / \mathrm{L}$ (calculated by $\left.\mathrm{CaCO}_{3}\right)$; and $\rho(\mathrm{Ca}) / \rho(\mathrm{Mg})$ of approximately $4: 1$.

In this experiment, eight aquatic animals and one kind of aquatic plant, which are commonly observed in China, including Pseudorasbora parva, Misgurnus anguillicaudatus, Macrobrachium nipponense, Cipangopaludina cathayensis, Bufo gargarizans, Limnodrilus hoffmeisteri, Daphnia magna, Scenedesmus obliquus and Chironomus riparius, have been chosen as the experimental objects to conduct acute toxicity experiments. Among these species, Scenedesmus obliquus belongs to the first trophic level; Chironomus riparius, Limnodrilus hoffmeisteri and Daphnia magna belong to the second trophic level; Pseudorasbora parva, Misgurnus anguillicaudatus, Macrobrachium nipponense, Cipangopaludina cathayensis and Bufo gargarizans belong to the third trophic level. The selected species could represent different trophic levels, and also meet the species needs of water quality criteria research. The experimental species were acclimated for 1 week prior to the beginning of the experiment (OECD, ASTM 2014). The exposure experiments with Pseudorasbora parva, Misgurnus anguillicaudatus, Macrobrachium nipponense, Cipangopaludina cathayensis, and Bufo gargarizans were conducted under flow-through experimental conditions. Experiments using Limnodrilus hoffmeisteri, Daphnia magna, Scenedesmus obliquus, and Chironomus riparius were conducted as semistatic experiments, and the water was changed every $24 \mathrm{~h}$. The illumination conditions during the experiment were light:dark times of $12 \mathrm{~h}: 12 \mathrm{~h}$, and the temperature of the circulating water bath was controlled at $20.0 \pm 1.0^{\circ} \mathrm{C}$. Ten experimental organisms were placed in each experimental cylinder. Exposure gradients of eight zinc concentrations were set up for each species. Based on the toxicity data of zinc to aquatic organisms in previous studies, the zinc gradient range of all species corresponding was between 0.025 and $64 \mathrm{mg} / \mathrm{L}$ (Feng et al. 2013; Liu et al. 2017; Wu et al. 2011). The $\mathrm{pH}$ value of each concentration was adjusted by 
using $\mathrm{HCl}$ and $\mathrm{NaOH}$. All the nominal and measured concentrations for zinc were listed in Table S1.

To avoid contamination from the gastrointestinal tract, species were starved for $24 \mathrm{~h}$ before the experiment. Temperature, $\mathrm{pH}$, dissolved oxygen and the total zinc concentrations in the solution were measured every $24 \mathrm{~h}$, and the state of the experimental animals was observed and recorded every $24 \mathrm{~h}$. The number of deaths of the tested species was recorded every day, and the $96 \mathrm{~h}$ or $48 \mathrm{~h}$ half-lethal concentration $\left(\mathrm{LC}_{50}\right)$ was calculated for the aquatic animals. But for Scenedesmus obliquus, half-effective concentration (EC50) is based on $96 \mathrm{~h}$-growth inhibition. The inhibition of growth was expressed as logarithmic algal biomass increase during the exposure period. Growth and growth inhibition were quantified from measurements of the algal biomass density.

Three replicates and one blank control were set up for each species under each $\mathrm{pH}$ value and zinc concentration. One-way analysis of variance (ANOVA) was performed on the treatment and control groups. Probability values less than 0.05 were considered as statistically significant. Concentrations of zinc before and after the experiment were measured. The within-treatment standard deviation values were less than $10 \%$. The mortality rates in the blank control groups were also less than $10 \%$. Concentrations of dissolved zinc were analyzed by inductively coupled plasma-mass spectrometry (ICP-MS, Agilent 7500a, USA). The main operating parameters of the instrumentation were as follows: radio-frequency power was $1500 \mathrm{~W}$; radio-frequency voltage was $1.85 \mathrm{~V}$; carrier gas flow was $1.22 \mathrm{~L} / \mathrm{min}$; sampling depth was $6.0 \mathrm{~mm}$. The limit of detection (LOD) of the instrumentation was $0.001 \mathrm{mg} / \mathrm{L}$.

The hazardous concentration of zinc was derived using the species sensitivity distribution (SSD) method. SSD was a data distribution fitting method. In brief, SSD mainly included four steps, including selecting of toxicity data, calculation of cumulative probability, data fitting and hazardous concentration extrapolation (Feng et al. 2013; Ministry of Environmental Protection of the People's Republic of China 2017; Wu et al. 2012). All the data were fitted by several models (e.g., logistic, normal, and value distribution). Finally, the estimated zinc concentration corresponding to the cumulative probability at the 5th percentile of the SSD curve was used to estimate the hazardous concentration of zinc.

\section{Results and Discussion}

It was found through the experimental study that the mortality of different aquatic organisms at different $\mathrm{pH}$ and zinc levels could be divided into three different groups (i.e., $\mathrm{pH}$ values between 3 and 8,8 and 10 , and greater than 10). At the first group ( $\mathrm{pH}$ range of 3-8), with the decrease in the
$\mathrm{pH}$ value in the aquatic environment, the mortality of all species had risen significantly under the same zinc dose level. Meanwhile, the growth inhibition of algae also increased. At the second group ( $\mathrm{pH}$ range of 8-10), even with relatively high zinc concentrations, the mortality of any of the nine test species did not rise above control levels (less than 5\%). At the third group ( $\mathrm{pH}$ greater than 10), the mortality of most species was close to $100 \%$, even at very low dissolved zinc concentrations in the water.

At present, the general view of the mechanisms of metal toxicity is that metal ions could combine with biological macromolecules in organisms such as protein, thus changing their activity. (Amiard-Triquet et al. 1998; Geffard et al. 2005). When zinc accumulates to a certain degree in organisms, the metal ion rate of entering an organism exceeds the synthesis rate of the metal-binding protein. The redundant metal ions will interact with other biological molecules in the body including enzymes and nucleic acids, thus causing poisoning. When $\mathrm{pH}$ in water is in the range of 3-8 at the first stage and there is a decrease in $\mathrm{pH}, \mathrm{Zn}^{2+}$ is easily absorbed and enriched by organisms because the main forms of zinc in water are changed from $\mathrm{Zn}(\mathrm{OH})_{4}{ }^{2-}, \mathrm{Zn}(\mathrm{OH})_{3}{ }^{-}$, $\mathrm{Zn}(\mathrm{OH})_{2}$ and $\mathrm{Zn}(\mathrm{OH})^{+}$to the dissolved free ionic form of $\mathrm{Zn}^{2+}$, and the toxicity of the simple positive ion $\mathrm{Zn}^{2+}$ is far greater than other forms of zinc. Further, the acidic enhancement can damage the tissues and organs of animals, so their resistance to zinc toxicity will be reduced. Therefore, the zinc toxicity of various kinds of organisms will increase with the reduction in the $\mathrm{pH}$ value. When $\mathrm{pH}$ in water is in the range of 8-10 at the second stage, the zinc toxicity does not increase with the increase in the concentration because most of the organisms can adapt to the weak alkaline condition. The $\mathrm{Zn}^{2+}$ and $\mathrm{OH}^{-}$mainly exist in the complexation form in the weak alkaline water, which greatly reduces the effective concentrations of the $\mathrm{Zn}^{2+}$ form in water. When the $\mathrm{pH}$ of the water is over ten, various kinds of organisms cannot adapt to the strong alkaline water. The mortality of various kinds of organisms is more than $95 \%$ even without zinc, which is obviously affected by the excessive hydroxide ion in water.

When the $\mathrm{pH}$ value of the water environment was seven, hydrogen ions had a rather small influence on the mortality of various organisms. All the $96-\mathrm{h} \mathrm{LC}_{50} / \mathrm{EC}_{50}$ values of the experimental species were acquired under the standard water conditions (Table 1). The rank of toxicity for of the nine test species to zinc was also obtained as follows: Scenedesmus obliquus $>$ Daphnia magna $>$ Limnodrilus hoffmeistteri $>$ Macrobrachium nipponensis $>$ Cipangopaludina cathayensis $>$ Chironomus riparius $>$ Pseudorasbora parva $>$ Bufo gargarizans $>$ Misgurnus anguillicaudatus. According to the above ranking, it can be easily determined that when the nutritional level of the lowerranked aquatic organisms remained low, the toxicity effect 
Table 1 Acute toxicity of zinc under different $\mathrm{pH}$ values $\left(\mathrm{LC}_{50} / \mathrm{EC}_{50}\right)(\mathrm{n}=81)$

\begin{tabular}{|c|c|c|c|c|c|c|c|c|c|}
\hline \multirow[t]{2}{*}{$\mathrm{pH}$ values } & \multicolumn{9}{|c|}{$\mathrm{LC}_{50} / \mathrm{EC}_{50} /(\mathrm{mg} / \mathrm{L})$} \\
\hline & $\begin{array}{l}\text { Scenedesmus } \\
\text { obliquus }\end{array}$ & Daphnia magna & $\begin{array}{l}\text { Limnodrilus } \\
\text { hoffmeisteri }\end{array}$ & $\begin{array}{l}\text { Macrobrachium } \\
\text { nipponense }\end{array}$ & $\begin{array}{l}\text { Cipangopalu- } \\
\text { dina cahayensis }\end{array}$ & $\begin{array}{l}\text { Chironomus } \\
\text { riparius }\end{array}$ & $\begin{array}{l}\text { Pseudorasbora } \\
\text { parva }\end{array}$ & $\begin{array}{l}\text { Misgurnus } \\
\text { anguillicau- } \\
\text { datus }\end{array}$ & $\begin{array}{l}\text { Bufo garga- } \\
\text { rizan }\end{array}$ \\
\hline 3 & - & - & - & - & - & - & - & - & - \\
\hline 4 & $0.057 \pm 0.004$ & $0.041 \pm 0.003$ & $0.11 \pm 0.014$ & - & $0.547 \pm 0.058$ & $1.59 \pm 0.158$ & $2.84 \pm 0.301$ & $6.61 \pm 0.575$ & $2.38 \pm 0.216$ \\
\hline 5 & $0.121 \pm 0.017$ & $0.054 \pm 0.005$ & $0.13 \pm 0.016$ & $1.12 \pm 0.132$ & $0.841 \pm 0.089$ & $4.99 \pm 0.518$ & $9.47 \pm 0.919$ & $11.90 \pm 1.314$ & $6.68 \pm 0.572$ \\
\hline 6 & $0.158 \pm 0.021$ & $0.101 \pm 0.011$ & $0.23 \pm 0.022$ & $2.50 \pm 0.217$ & $2.263 \pm 0.215$ & $9.57 \pm 1.106$ & $13.54 \pm 1.466$ & $23.75 \pm 3.154$ & $11.11 \pm 1.26$ \\
\hline 7 & $0.217 \pm 0.023$ & $0.233 \pm 0.026$ & $0.40 \pm 0.037$ & $2.96 \pm 0.304$ & $4.76 \pm 0.451$ & $13.71 \pm 1.163$ & $26.15 \pm 3.032$ & $35.98 \pm 4.095$ & $32.02 \pm 3.81$ \\
\hline $8-11$ & - & - & - & - & - & - & - & - & - \\
\hline
\end{tabular}

Data are expressed as mean \pm SD. "-" indicates that the value cannot be obtained through the calculation method

of zinc was more clearly exhibited by the smaller $\mathrm{LC}_{50}$ value. The lower trophic level organisms can easily absorb zinc and enrich the organisms. The tissues and organs of the animals with higher nutrition are relatively developed. Their abilities to internally detoxify and excrete zinc are stronger than those of the aquatic organisms at the lower trophic level.

When $\mathrm{pH}$ was seven, hydrogen ions have a rather small influence on the mortality of various organisms. Thus, in this study, the $\mathrm{LC}_{50} / \mathrm{EC}_{50}$ values of $\mathrm{pH}$ equal to seven were selected as the standard values for various species. As mentioned above, with the reduction in $\mathrm{pH}$ from 7 to 4 , zinc toxicity to various organisms had also increased. However, the degree of increase differed among the species. To quantify the degree of the $\mathrm{pH}$ influence on each species, all the $\mathrm{LC}_{50} / \mathrm{EC}_{50}$ values of $\mathrm{pH}$ equal to 4,5 and 6 were divided by the above acquired standard value of $\mathrm{LC}_{50} / \mathrm{EC}_{50}$ values, and then, the ratios of each were acquired, which could indicate the changes in zinc toxicity sensitivity of various organisms when $\mathrm{pH}$ decreased (Fig. 1). Statistical analysis showed that there was significant difference for each species in the process of $\mathrm{pH}$ decreasing from 7 to 4 . Moreover, significant differences among all the species were also observed. The toxicity effect of the reduction in $\mathrm{pH}$ on the lower trophic level aquatic organisms was not as obvious as that for the high trophic-level aquatic organisms such as fish or shrimp. The rank of various organisms' relative changes in sensitivity to zinc was Macrobrachium nipponensis $>$ Bufo gargarizans $>$ Cipangopaludina cathayensis $>$ Pseudorasbora parva $>$ Chironomus riparius $>$ Daphnia magna $>$ Misgurnus anguillicaudatus $>$ Llimnodrilus hoffmeistteri $>$ Scenedesmus obliquus. The reason might be that the lower trophic level organisms have a stronger capacity to adapt to acidic and alkaline water. At the same time, the peracid and peralkaline water environment causes more obvious damage to the tissues and organs of animals with high nutrition such as gill, lungs, or blood, which could greatly reduce the degradation and excretion, and toxicity resistance abilities of high aquatic animals such as fish and shrimp.
SSD method could well show differences in the sensitivities of the suite of nine species to zinc at the different test $\mathrm{pH}$ values. Individual SSDs for zinc acute toxicity under each of the test $\mathrm{pH}$ values were derived (Fig. 2). SSD modelfitting trials indicated that all the toxicity data were best fitted by logistic models. The best-fitting models gave an $\mathrm{R}^{2}$ greater than 0.95 . The results showed that the short-term hazardous concentrations (based on the 5th percentiles from each of the SSDs) $17.26 \mu \mathrm{g} / \mathrm{L}(\mathrm{pH}=4), 48.31 \mu \mathrm{g} / \mathrm{L}(\mathrm{pH}=5)$, $80.34 \mu \mathrm{g} / \mathrm{L}(\mathrm{pH}=6)$ and $230.6 \mu \mathrm{g} / \mathrm{L}(\mathrm{pH}=7)$, respectively. The short-term criteria for zinc have been previously derived to be $102.33 \mu \mathrm{g} / \mathrm{L}$ when $\mathrm{pH}$ was in the range of 6-9 (Liu et al. 2017). When $\mathrm{pH}$ was nearly 7 in a water environment, the water quality criteria of zinc was determined to be $115.3 \mu \mathrm{g} / \mathrm{L}$ using the SSD method, which was within $10 \%$ relative to the previous research. It was also found that zinc toxicity gradually increased with the constant decrease in the $\mathrm{pH}$ value in water. Hazardous concentration values would be reduced approximately two to three times with the reduction in $\mathrm{pH}$ values in the range of 4-7. This may be caused by the following reasons (Zvereva et al. 2003; Mazon et al. 1998): (1) the $\mathrm{pH}$ value in blood of aquatic animals changed greatly, and the oxygen carrying ability weakened, which resulted in hypoxia of aquatic animals. (2) It has a rather strong corrosive effect on the gill, skin and other tissues and organs of aquatic animals. (3) It has destructive effects on antioxidant enzymes and hydrolytic enzymes of the normal life of aquatic animals, resulting in metabolic disorder. (4) Peracid water would also cause a large number of bacteria and the reproduction of algae in water.

The current environmental quality standards for surface water in China are divided into five levels (GB 38382002) (Ministry of Environmental Protection of the People's Republic of China 2002). Class I standard is the most stringent, and Class $\mathrm{V}$ the least stringent. The five levels of zinc standards are $0.05,1,1,2$, and $2 \mathrm{mg} / \mathrm{L}$, respectively. Based on the measured concentrations of dissolved zinc in various aqueous solutions under different $\mathrm{pH}$ values, it could be found that when the $\mathrm{pH}$ was greater than 9 , 

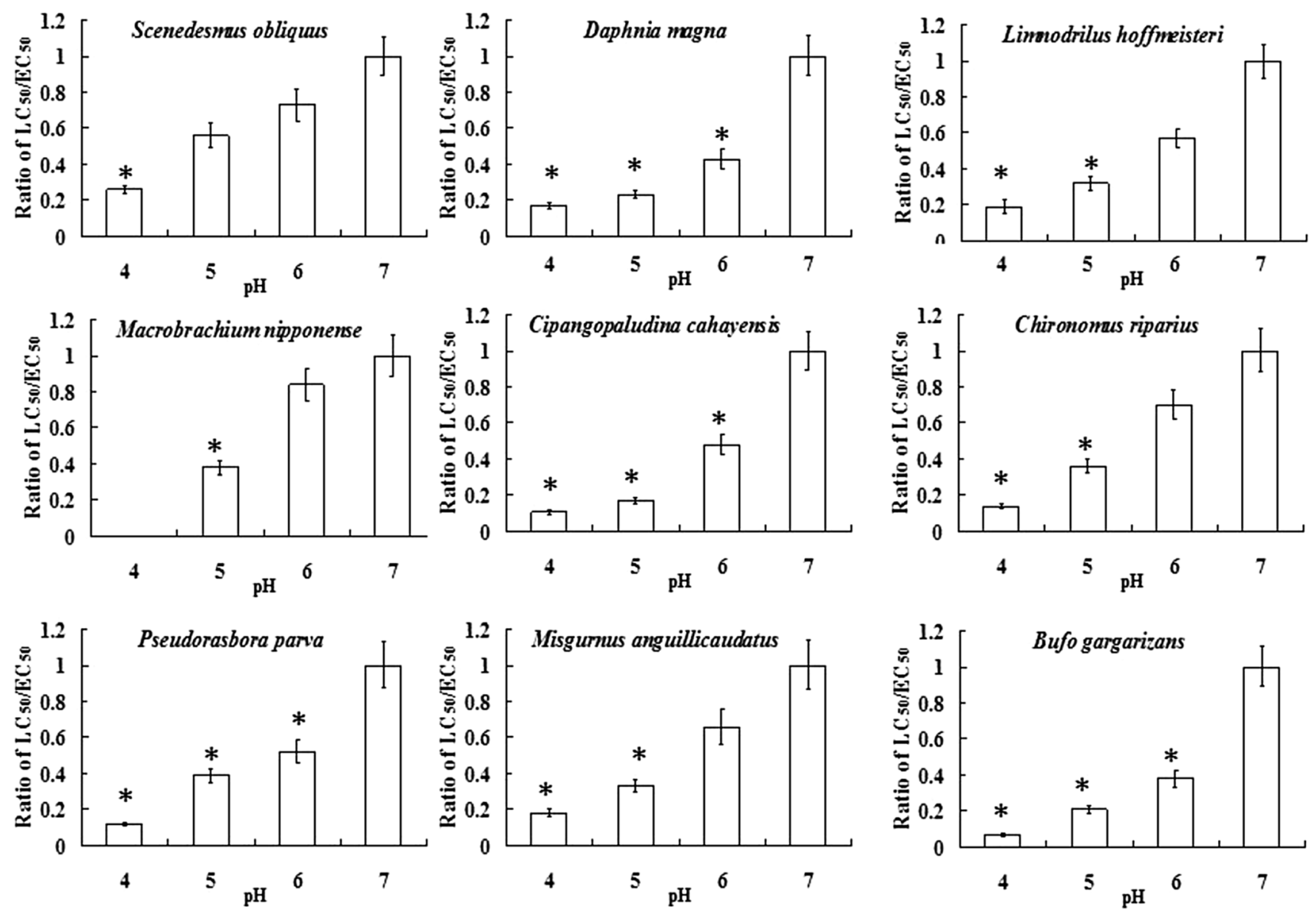

Fig. 1 The sensitivity of the experimental species to zinc toxicity ( $\mathrm{pH} 4-7$ ). Data are expressed as mean \pm SD; $* p<0.05$

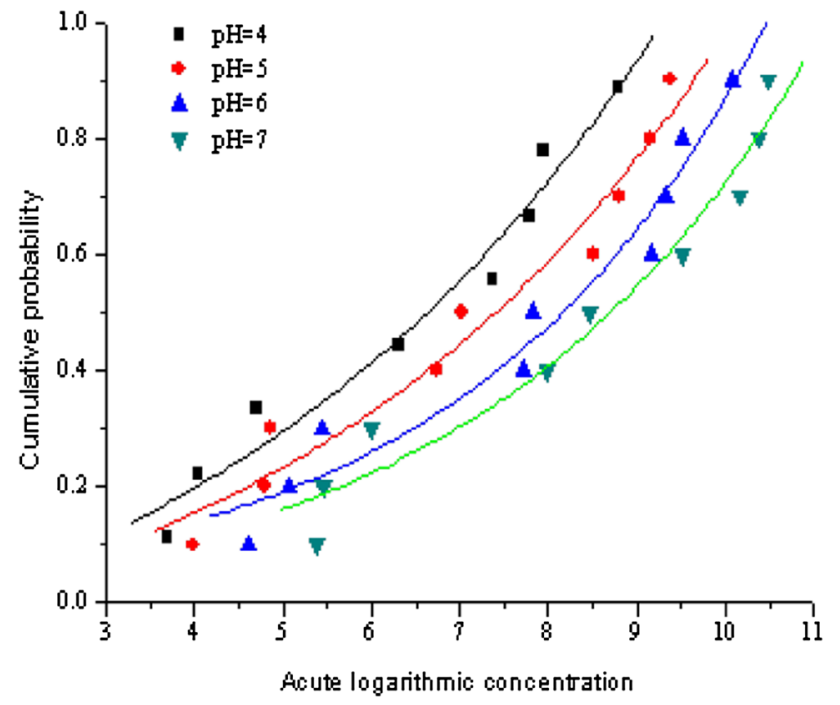

Fig. 2 Comparisons of species sensitivity distributions for zinc under different $\mathrm{pH}$ values the measured concentration is far less than the nominal concentration, and it was difficult to reach the class II-V standards. Therefore, it could be easily found that the current water quality standards for zinc, such as the environmental quality standards for surface water and fisheries, were suitable when the $\mathrm{pH}$ was between 7.0 and 8.0. Due to the significant influence of $\mathrm{pH}$ on zinc toxicity, in the actual water bodies, the standards of zinc will over-protect or under-protect aquatic organisms determined by the actual acidic or alkaline water environment with a wide range of $\mathrm{pH}$ values. Accordingly, various environmental factors, such as pH, water hardness and organic matter, considered as an integrated chemical system, should be taken into consideration in the validation and revision of current standards for metals in Chinese waters in the near future.

Acknowledgements This study was supported by China's National Natural Science Foundation, "Studies on Influence Mechanism of Zinc Bioavailability in Lake Water Environment" (41503100). 


\section{Compliance with Ethical Standards}

Conflict of interest The authors declare that they have no conflict of interest.

Open Access This article is distributed under the terms of the Creative Commons Attribution 4.0 International License (http://creativeco mmons.org/licenses/by/4.0/), which permits unrestricted use, distribution, and reproduction in any medium, provided you give appropriate credit to the original author(s) and the source, provide a link to the Creative Commons license, and indicate if changes were made.

\section{References}

Alsop DH, Wood CM (1999) Influence of waterborne cations on zinc uptake and toxicity in rainbow trout, Oncorhynchus mykiss. Can J Fish Aquat Sci 56(11):2112-2119

Amiard-Triquet C, Rainglet F, Larroux C, Rogoli F, Hummel H (1998) Metallothionein in Arctic bivalves. Ecotoxicol Environ Saf 41(1):96-102

And SN, Wood CM (2004) Biotic ligand model, a flexible tool for developing site-specific water quality guidelines for metals. Environ Sci Technol 38(23):6177-6192

ASTM E1192-97 (2014) Standard guide for conducting acute toxicity tests on aqueous ambient samples and effluents with fishes, macro invertebrates, and amphibians. United States: American Society for Testing and Materials, Washington DC

Chen ZZ, Zhu L, Wilkinson K (2010) Validation of the biotic ligand model in metal mixtures: bioaccumulation of lead and copper. Environ Sci Technol 44:3580-3586

Clifford M, McGeer JC (2009) Development of a biotic ligand model for the acute toxicity of zinc to Daphnia pulex in soft waters. Aquat Toxicol 91(1):26-32

Diamantino TC, Almeida E, Soares AMVW, Guilhermino L (2003) Characterization of cholinesterases from Daphnia magna straus and their inhibition by zinc. Bull Environ Contam Toxicol 71(2):219-225

Feng CL, Wu FC, Chang H, Zhao XL (2013) Derivation of freshwater quality criteria for zinc using interspecies correlation estimation models to protect aquatic life in China. Chemosphere 90:1177-1183

Fu ZY, Wu FC, Chen LL, Xu BB, Feng CL, Bai YC, Liao HQ, Sun SY, Giesy JP, Guo WJ (2016) Copper and zinc, but not other priority toxic metals, pose risks to native aquatic species in a large urban lake in Eastern China. Environ Pollut 219:1069-1076

Geffard A, Amiard-Triquet C, Amiard JC (2005) Do seasonal changes affect metallothionein induction by metals in mussels. Mytilus edulis? Ecotoxicol Environ Saf 61(2):209-220

Guo CQ, Feng JC (2013) Zinc market analysis and outlook. China Nonferr Metals 2:44-45 (in Chinese)

Heijerick DG, Janssen CR, Coen WMD (2003) The combined effects of hardness, $\mathrm{pH}$, and dissolved organic carbon on the chronic toxicity of $\mathrm{Zn}$ to D. magna: development of a surface response model. Arch Environ Contam Toxicol 44(2):210-217

Karntanut W, Pascoe D (2002) The toxicity of copper, cadmium and zinc to four different hydra (Cnidaria: Hydrozoa). Chemosphere 47(10):1059-1064

Lindholmer C (1974) Toxicity of zinc ions to human spermatozoa and the influence of albumin. Andrologia 6(1):7-16

Liu DQ, Li XF, Fu WQ, Huang CH, Yang H, Feng CL (2017) Water quality criteria of zinc for the protection of freshwater organisms and its ecological risk in China. Environ Eng 35(9):18-23 (in Chinese)

Mazon LI, Gonzalez G, Vicario AL, Estomba A, Aguirre A (1998) Inhibition of esterases in the marine gastropod Littorina littorea exposed to cadmium. Ecotoxicol Environ Saf 41(3):284-287
Ministry of Environmental Protection of the People's Republic of China (2002) GB 3838-2002 Surface water environmental quality standard. China Standards Press, Beijing (in Chinese)

Ministry of Environmental Protection of the People's Republic of China (2017) HJ 831-2017. Technical guideline for deriving water quality criteria for the protection of freshwater aquatic organism. China Standards Press, Beijing (in Chinese)

Mottin E, Caplat C, Mahaut ML, Costil K, Barillier D, Lebel JM, Serpentini A (2010) Effect of in vitro exposure to zinc on immunological parameters of haemocytes from the marine gastropod Haliotis tuberculata. Fish Shellfish Immun 29(5):846-853

Muyssen BT, Janssen CR (2007) Age and exposure duration as a factor influencing $\mathrm{Cu}$ and $\mathrm{Zn}$ toxicity toward Daphnia magna. Ecotoxicol Environ Saf 68(3):436-442

Nor YM (1990) Effects of organic ligands on toxicity of copper and zinc to Carassius auratus. Chem Spec Bioavailab 2(3):111-115

OECD (1992) Guidelines for the testing of chemicals, sect. 2: effects on biotic systems, test no. 203: fish, acute toxicity test. Organisation for Economic Co-operation and Development, Paris

OECD (2004) Guidelines for the testing of chemicals, sect. 2: effects on biotic systems, test no. 202: Daphnia sp, acute immobilisation test. Organisation for Economic Co-operation and Development, Paris

OECD (2011) Guidelines for the testing of chemicals, sect. 2: effects on biotic systems, test no. 201: freshwater alga and cyanobacteria, growth inhibition test. Organisation for Economic Co-operation and Development, Paris

Ryan AC, Tomasso JR, Klaine SJ (2009) Influence of pH, hardness, dissolved organic carbon concentration and dissolved organic matter source on the acute toxicity of copper to Daphnia magna in soft waters: implications for the biotic ligand model. Environ Toxicol Chem 28(8):1663-1670

Schamphelaere KAD, Loft S, Janssen CR (2005) Bioavailability models for predicting acute and chronic toxicity of zinc to algae, Daphnids, and fish in natural surface waters. Environ Toxicol Chem 24(5):1190-1197

Smirnova ON, MelNichenko EI (1997) Study of zinc and cadmium chloride toxicity using human embryo fibroblast cultures. Gigiena Truda I Professionalnye Zabolevaniia 7:49-50

US EPA (2007) Aquatic life ambient freshwater quality criteria-znic. Office of Water Regulations and Standards Criteria Division, Washington DC

US EPA (2009) National recommended water quality criteria. Office of Water, Office of Science and Technology, Washington DC

Wadige CPMM, Taylor AM, Maher WA, Krikowa F (2017) Bioavailability and toxicity of zinc from contaminated freshwater sediments: linking exposure-dose-response relationships of the freshwater bivalve Hyridella australis to zinc-spiked sediments. Aquat Toxicol 156:179-190

Wang WN, Liang H, Wang A (2000) Effect of $\mathrm{pH}$ and $\mathrm{Zn}^{2+}$ on subcultured muscle cells from Macrobrachium nipponense. Method Cell Sci 22(4):277-284

Wang XD, Ma YB, Liu H (2006) Prediction model of metal biological effectiveness in the environment-research progress of biological ligand model. Asian J Ecotoxicol 1(3):193-202

Wu FC, Feng CL, Cao YJ, Zhang RQ, Li HX, Zhao XL (2011) Study on the toxicity characteristics and water quality of fresh water by zinc. Asian J Ecotoxicol 6(4):367-382 (in Chinese)

Wu FC, Feng CL, Zhang RQ (2012) Research on water quality of typical pollutants in China. China Sci 42(5):665-672

You L, Cui L, Liu Z, Yang B (2007) Correlation analysis of parameters in algal growth. Environ Sci Technol 30:9:42-44 (in Chinese)

Yu T, Zhang Y, Wu F, Meng W (2013) Six-decade change in water chemistry of large freshwater Lake Taihu, China. Environ Sci Technol 47:9093-9101 
Zhang YH, Zang WC, Qin LM (2017) Water quality criteria for copper based on the BLM approach in the freshwater in China. PLoS ONE 6: $2362-2371$

Zhao N, Zhu L, Feng MF (2010) The toxicological effects of $\mathrm{Cr}^{6+}$ on Chlorella vulgaris, Scenedesmus obliquus and Microcystis aeruginosa at different $\mathrm{pH}$ values. Asian J Ecotoxicol 5(5):657-665
Zvereva E, Serebrov V, Glupov V, Dubovskiy I (2003) Activity and heavy metal resistance of non-specific esterases in leaf beetle Chrysomela lapponica from polluted and unpolluted habitats. Comp Biochem Physiol C 135(135):383-391 